\title{
Using Passive Energy Systems in Ecofarm ArChitecture
}

\section{Györgyi Csontos}

Institute of Architecture,

Ybl Miklós Faculty of Architecture and Civil Engineering, Szent István University, Budapest, Hungary csontos.gyorgyi@ybl.szie.hu

\begin{abstract}
The history of eco (organic) farming in Hungary has begun in 1983. Currently, approx. 2\% of the agricultural area is managed this way. This research gives a survey on the architectural backgrounds of this specific land management type.

Sustainability and energy conservation have brought along a new demand in the construction industry, including design and operation of agricultural buildings: the usage of energy efficient, environmentally friendly and preferably renewable energy based building alternatives.

Among the energy-saving solutions we have to emphasize those passive systems in particular, which use the natural conditions (sunlight, shading, ventilation, gravity, etc.) on their own, without the help of mechanical equipment, and achieve energy efficiency by placing and structuring technological buildings accordingly.
\end{abstract}

Keywords: Eco (organic) farming, Agricultural architecture, Sustainability, Renewable energy, Passive systems

\section{GENERAL PRINCIPLES}

\subsection{Eco farms, energy saving}

The story of Hungarian bio- (eco) farming started nearly thirty years ago in 1983 with the foundation of Bioklub. Presently ecological farming is pursued on approximately 120000 hectares, $2 \%$ of the cultivable area in Hungary. According to a survey of Biokontroll, at the beginning of 2013 there were 1137 eco farms in our country which met EU standards by not using artificial or synthetic tools and materials. (The other qualifying organization - Hungária Ökogarancia - registered 94 producer at the same time.)

The market of bio food is growing all over the world. This trend is expected to appear in Hungary, as well. The Hungarian countryside is suitable for adapting special low scale production methods besides large scale technologies. 
Considerable progress could also be achieved by reinterpreting and updating traditional technologies (Figure 1).

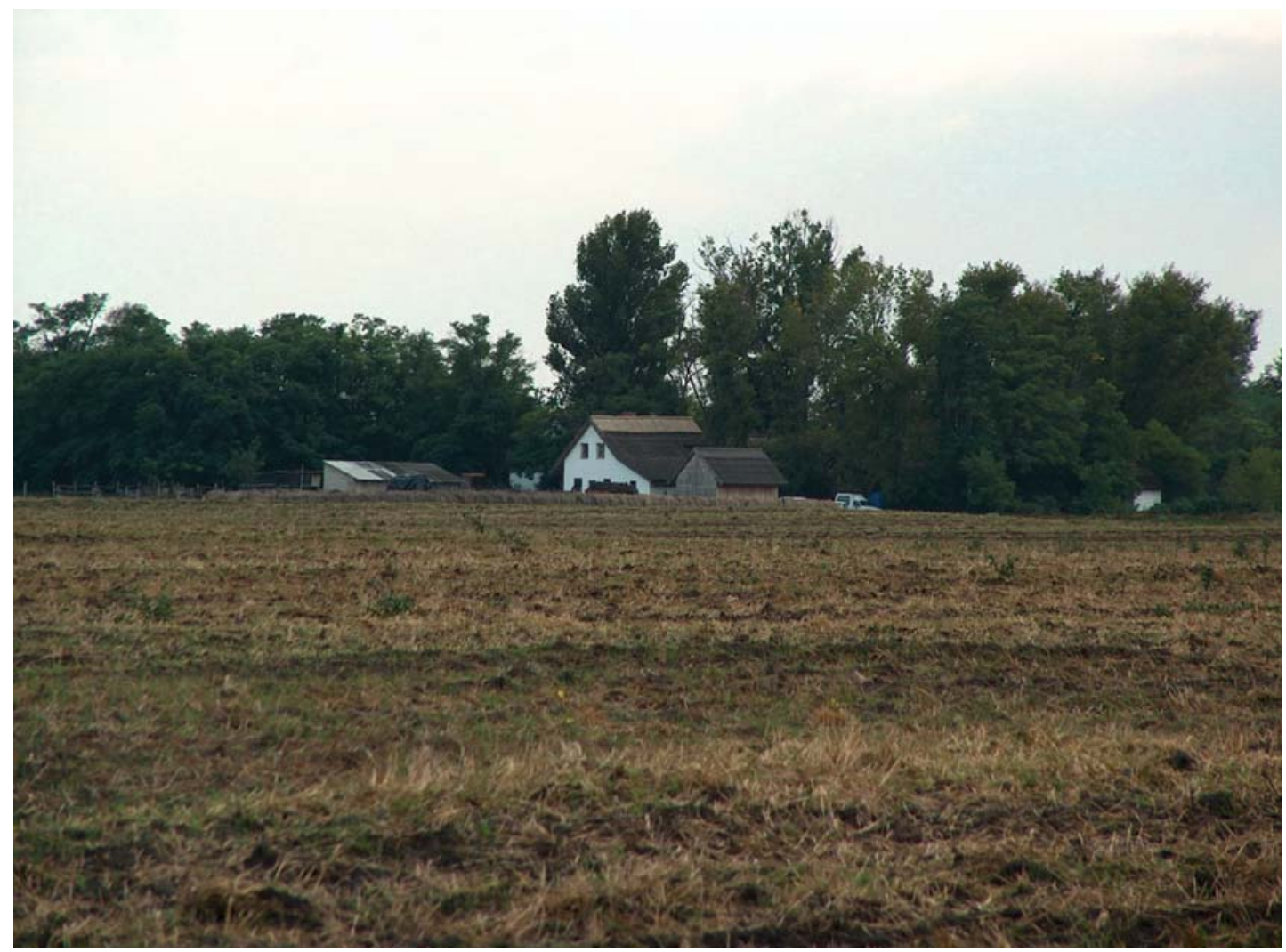

Figure 1 Buildings of the Eco Farm of Kerekegyháza fitted in their natural environment (architect: Dr. Gábor Reischl)

Sustainability and energy saving are key issues of our times. Phenomena like energy crisis and climate change have made architecture - including agricultural design - aware of the importance of using economical and environment-friendly solutions based on renewable energy.

\subsection{Using passive energy in agriculture}

Solar technologies are broadly characterized as either passive or active depending on the way of converting sunlight to heat. Passive techniques utilize and store solar energy directly with the help of architectural devices without applying special machineries [1]. Due to purposeful structuring and orientation these buildings efficiently utilize passive energies and exploit natural resources like sunlight, shading, gravitational ventilation, et cetera (Figure 2, 3). 


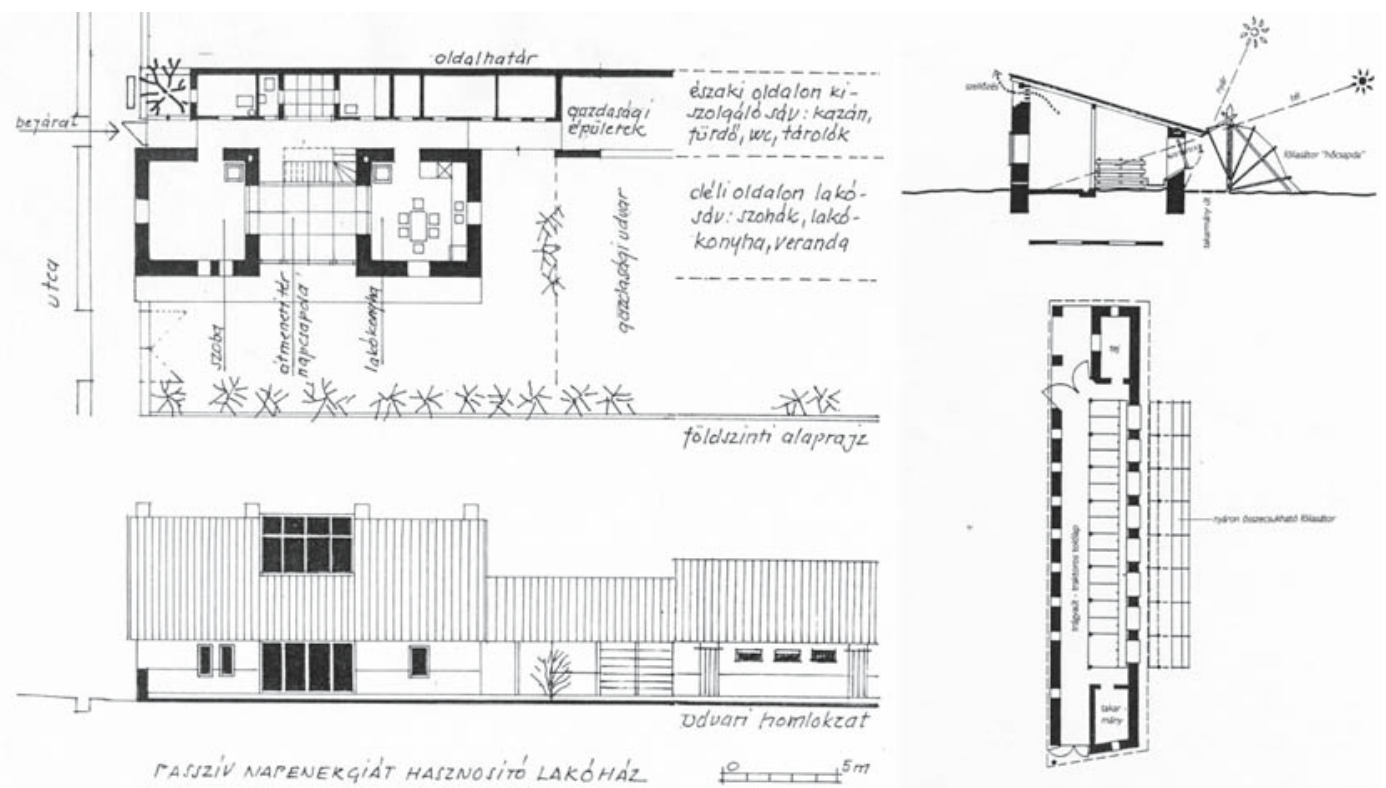

Figure 2-3 Residential building and stable utilizing passive energy with sun space and a mobile foil tent (architect: Dr. Gábor Reischl, Zsuzsa Netkovszky)

Passive solar energy utilizing systems can be grouped as direct or indirect. Direct systems are for examples the scattering-free and scattering systems in the course of light absorption and some of the solar spaces. Indirect systems are the energy-collecting walls and roofs, the airheat conveying systems and other forms of sun spaces. (See agricultural glass- and foil houses (Figure 4, 5).)
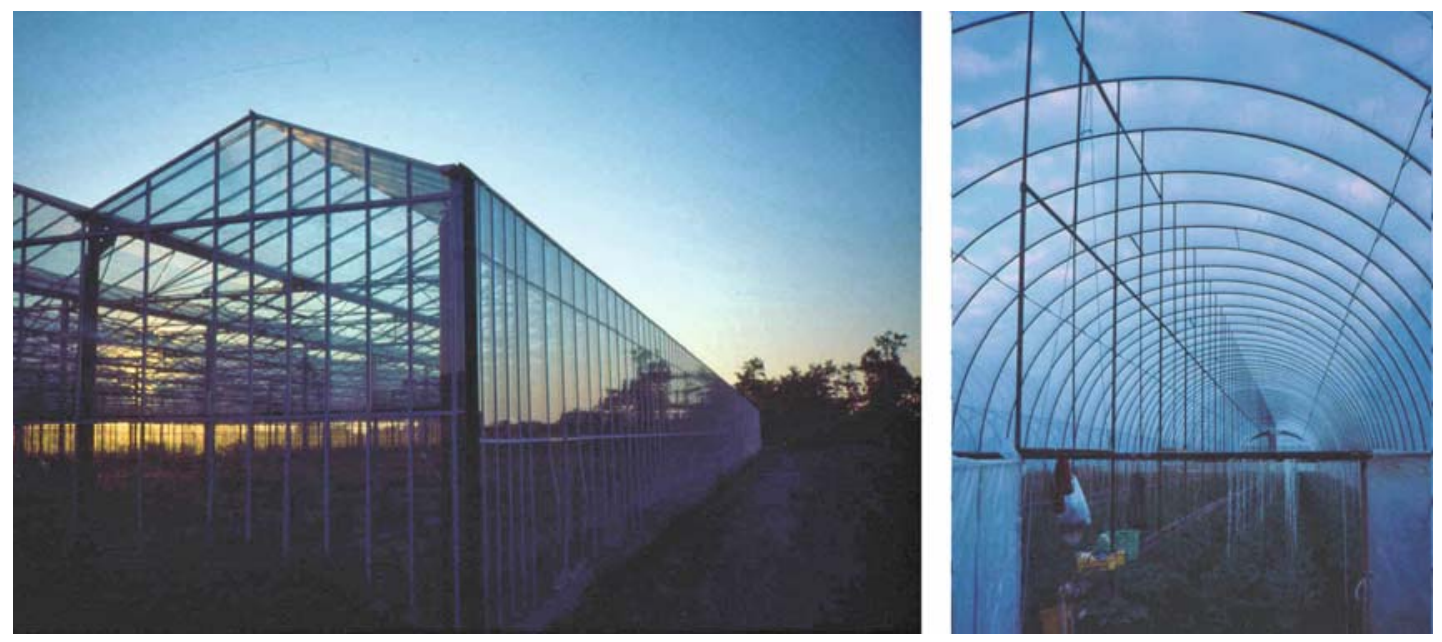

Figure 4-5 Glass- and foil houses 
The main fields of passive energy application in agricultural architecture are ventilation, heating and cooling. However the regulation of temperature changes and humidity or the application of certain farming technologies can also be greatly economized by using passive energy.

Energy saving is considered not only in the operation of a building but also in the course of its construction for example by choosing cost effective materials or thorough pre-planning further developments. The opportunity of converting or developing the building technologically with the least possible energy usage has to be created during the designing phase (Figure 6,7).
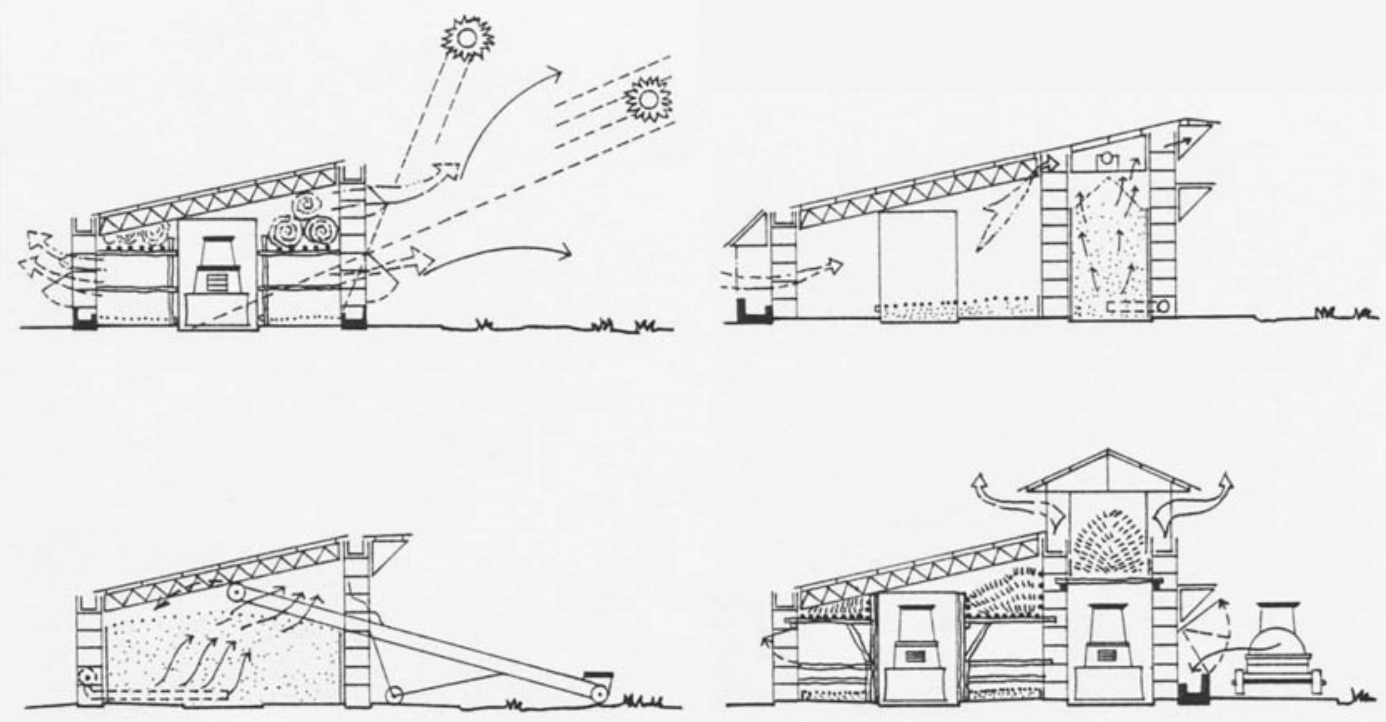

Figure 6-7 Developable, multifunctional, material saving buildings converted from bound to unbound cattle keeping and storing crops; and from storing crops cattle keeping in boxes [6]

\subsection{Specific features of the architecture of environmentally conscious eco farms in respect of passive energy usage}

\section{Principles of location}

When locating a building the decisive direction of wind, solar radiation and other effects of the microclimate (humidity, fogginess, cold currents, et cetera) should be taken into consideration as these elements could affect the behaviour of animals. Good siting is particularly important in case of extreme weather conditions (Figure 8). 


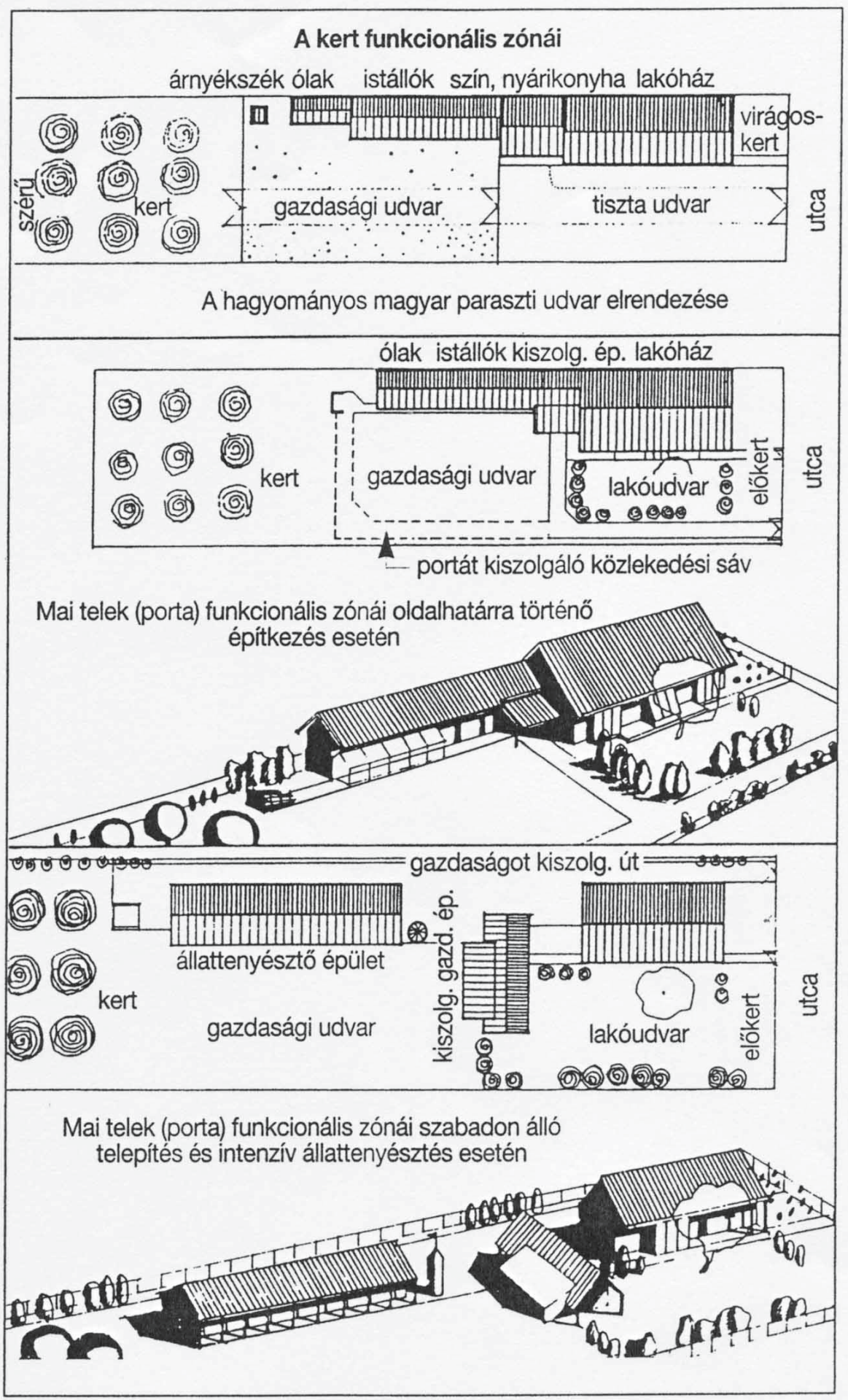

Figure 8 Characteristics of siting traditional and contemporary estates [6] 
An optimal amount of solar radiation has positive effect on living beings and their environment (i.e. disinfection), but they must be protected from excessive radiation. A well sited and oriented building lets in sunshine in winter, and closes it off in summer. The southern and northern facades of these buildings are differentiated. The southern façades are usually open whereas the northern façades are mostly closed. The southern façade has to be protected against solar radiation with architectural devices (i.e. projecting roof) or plants (i.e. vine-arbour). The northern façade can be partly opened in order to ensure ventilation (draught) in summer but it must be provided with heat-insulation in winter [1].

Conscious or instinctive elements of energy, material, water or air usage can be traced when examining the orientation of old farms or plots of land; the functional arrangement and structuring of residential and farming buildings. Due to the good orientation, buildings (mostly residential buildings) requiring more heat, are placed on the less advantageous side of the plot. Their northern facades are almost totally closed (apart from blowholes), while the southern facades are open. The doors and windows of the buildings requiring cooler climate (cellars, cook-houses, clamps, et cetera) are oriented towards north and are better shaded. Among others this double-demand orientation has resulted in yard siting, where the centre of the complex is not the residential building but the yard. Conscious planting also plays a significant role in heat ecology [2] (Figure 9, 10).
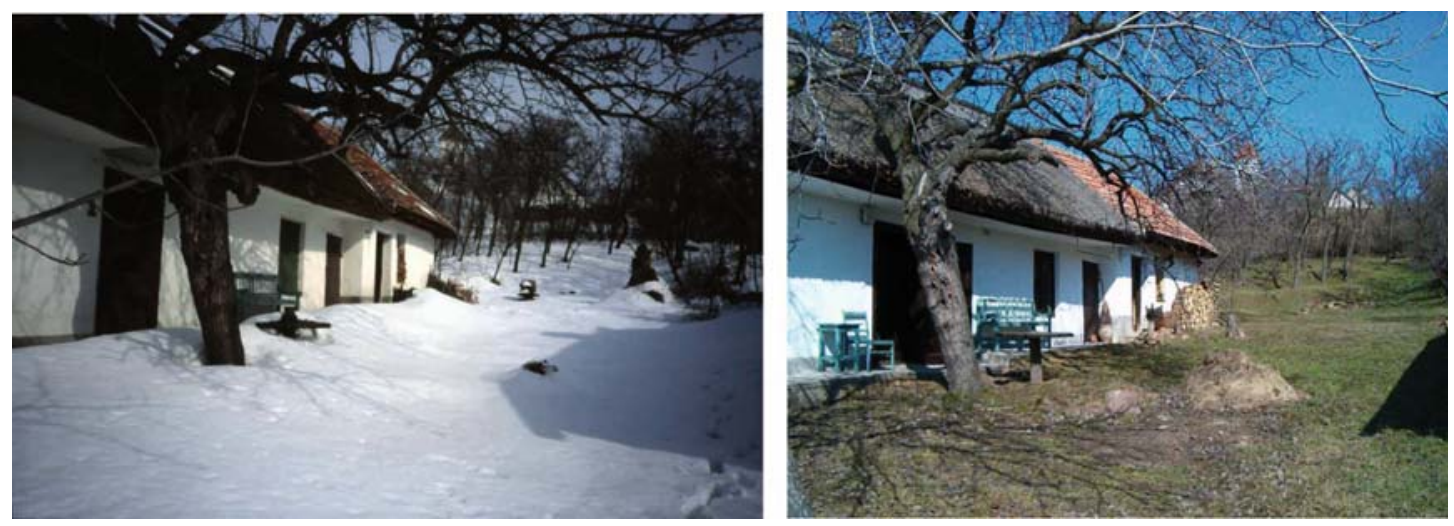

Figure 9-10 Residential building and farming buildings built behind it in a village estate with the winter and summer shading of the porch

\section{Units of farm buildings utilizing passive energy}

Sun spaces are probably the best known units of architectural utilization of solar energy [3]. Their versions applied in agriculture are greenhouses, glasshouses and open barns. Residential and social buildings, transitory spaces and zones of stables, porches, verandas, sun lounges and flower windows also support energy efficiency [2].

As far as the structures of greenhouses are concerned, they are usually lithe, metal-framed structures with opening parts made of glass or plain or bent polycarbonate sheets on their top or side surfaces. There are horizontal-volume (single-span) and block lined (multi-span) greenhouses. 
They are usually symmetric, but in Hungary, and in the temperate zone in general, its lean-to version functions properly. (Sometimes they are attached to the southern side of another farming building.)

Presently applied foil houses have rounded forms, so compared to traditional greenhouse forms they get 10 to $15 \%$ more light. The main types of foil culture apparatuses are the foil tunnel, the foil bed, the foil tent and the foil block [3].

\section{Forming principles and structures of energy-conscious farming buildings}

As regards doors, windows and blowholes, in closed buildings an appropriate (adjustable and optimal) natural ventilation and lighting must be ensured. Doors and gates must be made in a measure and opening direction accommodating to the holding technology. If necessary, they have to be provided with heat-insulation. Natural, draught-free ventilation can be supported by the installation of calibrated ridge ventilators, even if there is built-in curtain system regulating winter wind protection. The open sidewalls ensure permanent natural air flow and ventilation (Figure 11, 12, 13).
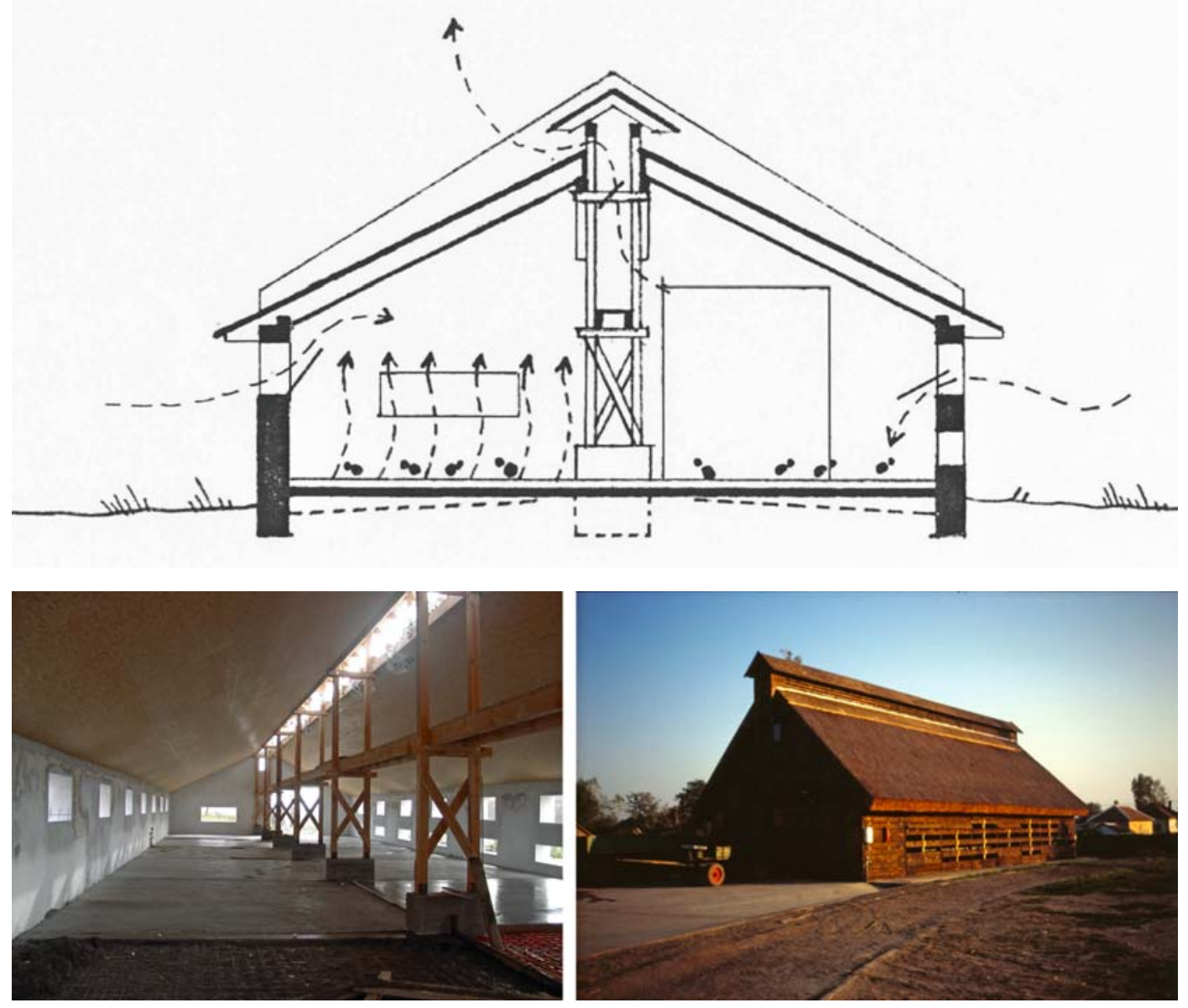

Figure 11-13 Application of ridge ventilators in a bio hen house and a multifunctional storing building (architects: Dr. Gábor Reischl, Zoltán Laczó) 
Heat-insulation is necessary not only in the enclosing structures (wall, floor and roof structures) of closed stock breeding buildings in winter, but also in the roof structures of partly opened buildings to lessen summer heat loading. Winter heat-insulation (under widely projecting eaves) can be carried out with straw bale, bedding straw in floors and damp-resisting ventilating heatinsulating material (i.e. fibreglass) built between the principals in roof structures [4] (Figure $14,15,16)$.
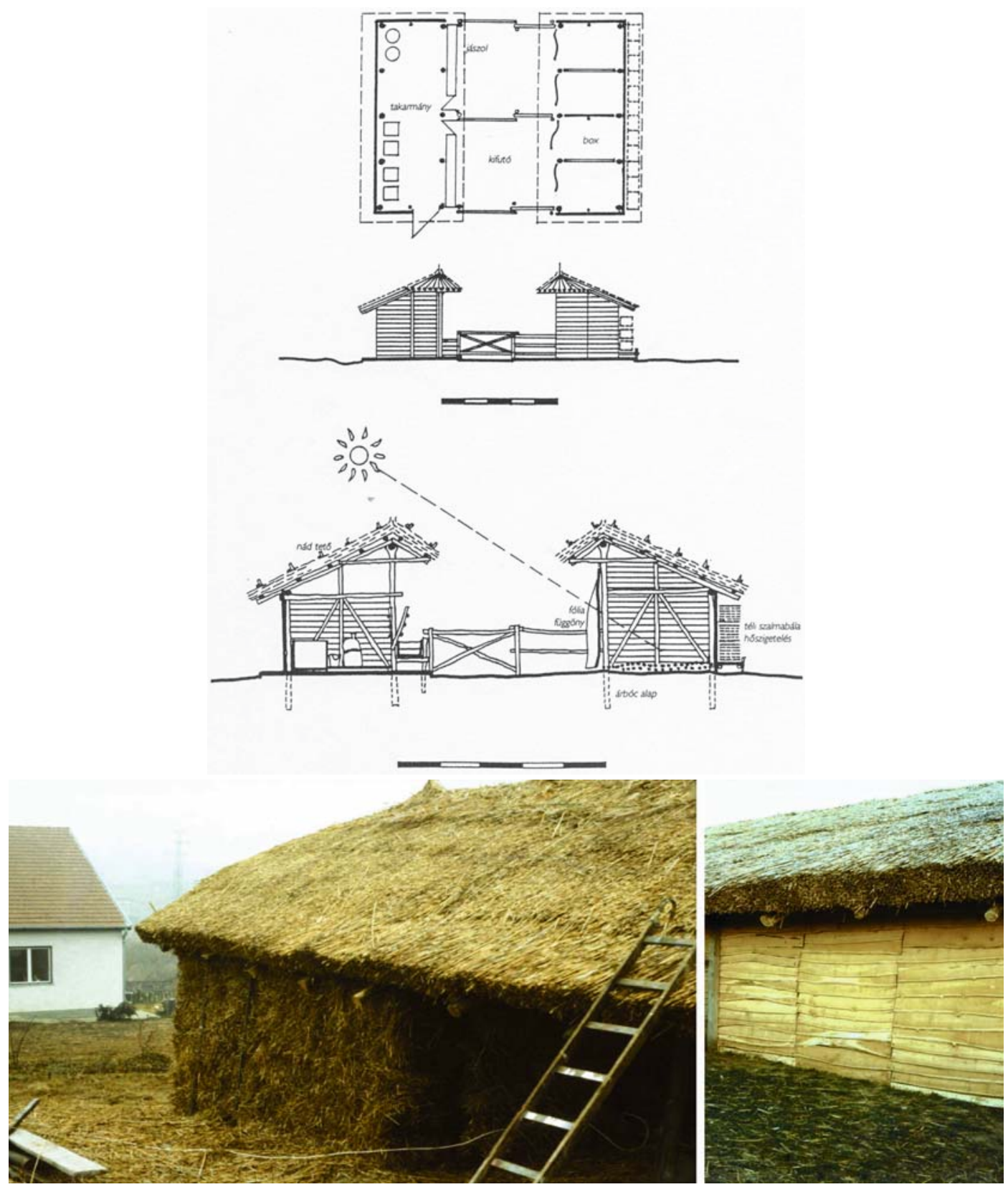

Figure 14-16 Placement of fodder insulation in a cost-effective cow shed in Bercel (architect: Dr. Gábor Ónodi) 


\section{PLANTS - CULTIVATION AND STORAGE}

\subsection{Cultivation}

Well adjustable ventilation is a prerequisite of effective operation of greenhouses. As regards passive energy usage the application of ridge ventilators is inevitable. In order to ensure natural ventilation, ten to fifteen percentage of the glass surface should be convertible. The efficiency of passive heating is affected by the size and light transmission of the transparent coverings and also the degree of vapour and ventilation. The simplest way of shading greenhouses is temporarily darkening the glass panes with removable paint. The application of adjustable mobile inner or outer synthetic drapes, textiles or shutters means higher standard solutions. To reduce heat loss in foil beds and foil tents we can apply double foil covering, water curtain foil tents, passive solar containers (black plastic sacs filled with water) or double layered blown foil covering (Figure 17).

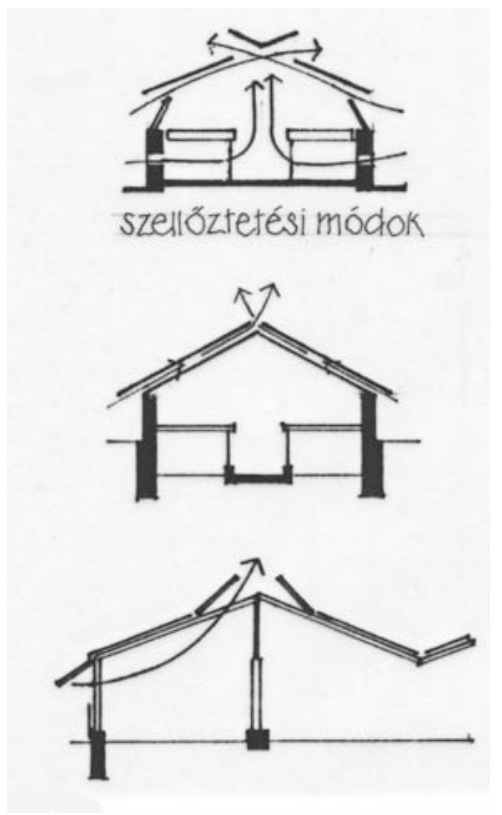

Figure 17 Ventilating schemes of greenhouses [6]

\subsection{Storage}

As far as storing premises are concerned the knowledge of local geographical and weather data can help the optimal utilization of natural ventilation, the application of solar energy systems, the utilization of heat storing capacity of the soil or the conscious application of precipitation and water management. Large floor-space and facades broken by very few windows are general characteristics of storing buildings. The large roof and façade surfaces facilitate the installation of solar energy systems. 


\section{Grain crops storage}

Cribs - which are primarily used for storing corn - are a basic type of traditional crops storing buildings. Their shape and parameters are determined by the drying requirements of the stored crops and the weather specialities of the place (amount of precipitation, number of sunny hours). While in the rainy western regions of the country 1.10 to 1.20 metre wide cribs can be built safely, in the southern territories around the city of Szeged or in the Bánság corn does not get mouldy in 1.80 to 2.00 metre wide cribs.

Granaries are the other widespread type of traditional grain crops storing buildings. These multi-storeyed buildings are usually built of stone or brick with small ventilator windows and huge wooden joist structures.

When designing a grain crops storing building with 6000 tons capacity in Balatonfenyves the application of a simple technological system utilizing the logic of traditional storing systems, was a primary concern. The rotating conveyor belt placed in the centre of the 30.00 square metre inner yard, can convey crops to each section of the building through funnelled chutes, which also function as means of natural ventilation and lighting. Grains are spread in natural slope angle. Quality control can easily be maintained from the upper service walkway from where the openings can also be regulated (Figure 18, 19, 20).
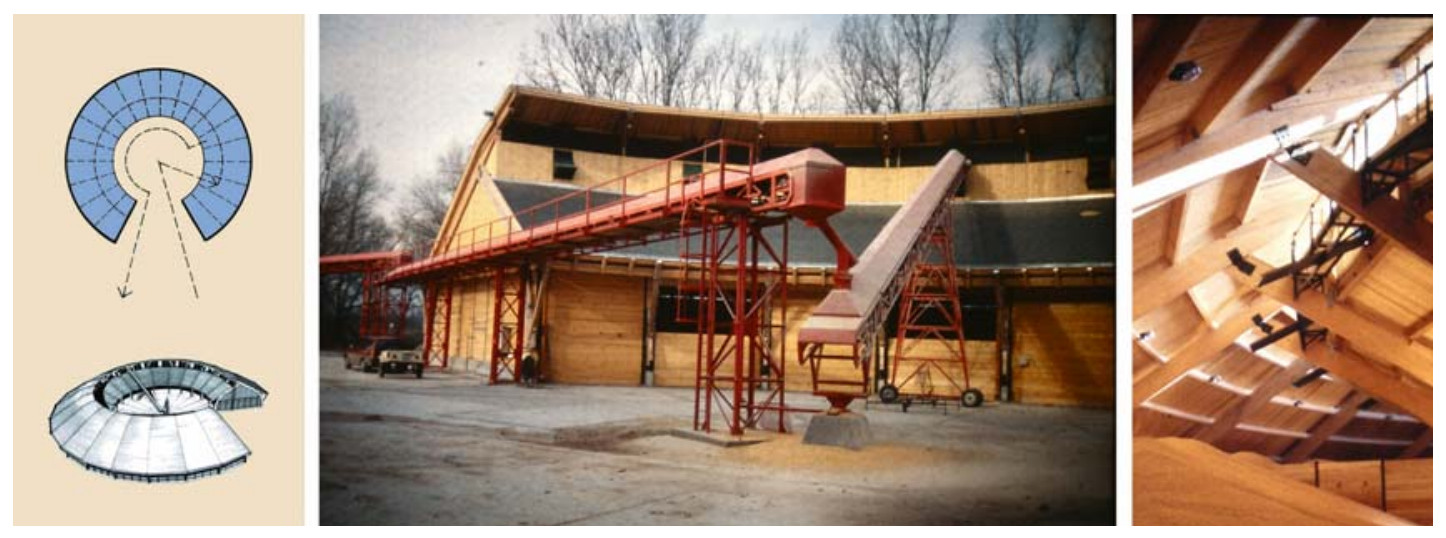

Figure 18-20 Operational principle of the with 6000 tons grain crops storing building in

Balatonfenyves and the feeding, ventilating and lighting opening from outside and inside (architect:

Dr. Gábor Reischl)

The multifunctional building of the Farming School in Kenderes is operating by the principle of traditional tobacco drying sheds. By means of size coordination it is suitable for taking on various functions. From the service walkway in the middle sector the ridge ventilator can easily be opened and closed, the quality of the stored material can be controlled and the different technological equipment and devices (e. g. gathering pulleys) can be installed and fixed [2] (Figure 21). 


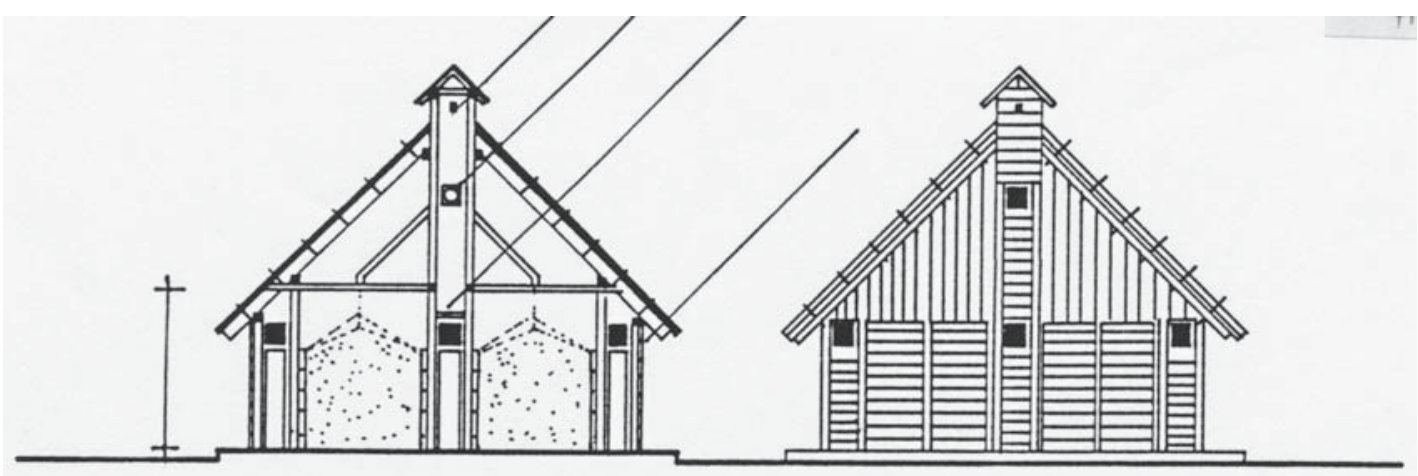

Figure 21 Storing building in Kenderes with its middle and side section ventilating system (architect: Dr. Gábor Reischl)

\section{Fruit storage}

Permanent temperature and humidity with adjustable ventilation is of fundamental importance in case of storing fruit as well. Natural storing conditions can be reproduced by building cellarlike clamps, where the covering earth layer reduces the effect of changes of temperature and ensures proper humidity. The means of manually operated natural ventilation are the underneath ventilator pipes placed in the ground, which are practically stowed on the longitudinal side of the building. Appropriate air flow is provided by a ventilator fixed on the ridge of roof.

In case of pre-fabricated buildings it is also advisable to apply traditional architectural "tricks" like the so-called "cold roof". The heat load of the building can significantly lessened by the flow of hot air in the ventilated air layer between the heat-insulated flat floor and the metal roofing. It is worth shading the facades exposed to sunshine for example by appropriately planted plants, an attached open building part or a projecting roof (Figure 22).
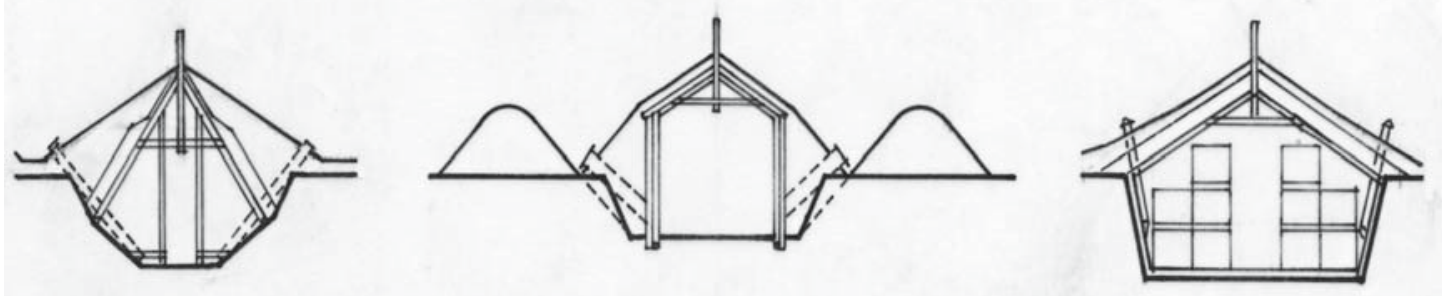

Figure 22 Fruit storing buildings sunk in the ground with underneath and ridge ventilation [6]

\section{Vegetable storage}

The permanent optimal temperature and humidity and appropriate ventilation is essential in vegetable storing buildings as well. Natural vegetable storing methods can basically be divided into two groups: claps, prisms, stacks and built storing houses. 
The ventilation of the buildings can be ensured by underneath and ridge air-drains.

Relative humidity suited to the water-content of the vegetables must be ensured. Humidity can be increased by watering the paths of the storing space and can be reduced by airing or putting in absorbent materials like common salt. The amount of hourly changed air of the storing space can 13 to 15 times as large as in fruit storing buildings (Figure 23).
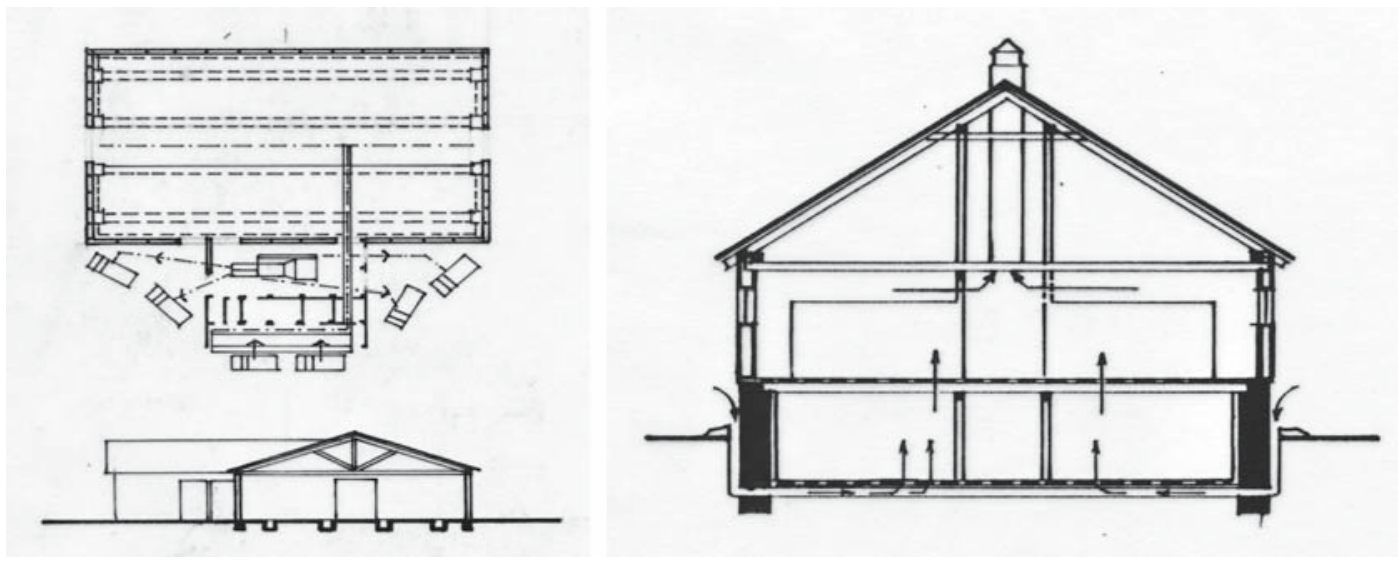

Figure 23 Built vegetable storing buildings with two-level underneath and floor channel ventilation [6]

\section{Wine storage}

When building cellars into the ground or under a building the primary environmental concern is to moderate the changes of temperature and ensure adequate humidity and ventilation.

The best result is achieved when the cellar is built into a hillside, but even in the most favourable circumstances ventilation must be solved by architectural means as well. Gravitational ventilation is carried out through air-ducts going to open air. The operability of the system depends on the difference between the outer and inner air temperature, the rate of outer air flow and the sizes (cross-section, length) of the ventilation ducts. For the sake of balanced ventilation it is more effective to use more pipes with narrower cross-section than fewer ones with wider cross-section. In case of hillside cellars one duct with 20 centimetre cross-section is applied for 300 square metres. The blow hole is on the highest point of the ceiling. In order to moderate indoor temperature changes of the presser room it is advisable to apply small-size windows and "heavy" doors just like in traditional architecture.

In case of built cellars it is also useful to apply a solution similar to the earth covering of hillside cellars. The walls and the brick vault must be provided with three layered earthen water insulation and a minimum 1.00 metre thick earth covering.

Cellars placed under a building must be properly isolated from residential spaces. In this case vaulted cellars are not only aesthetically justified. The filling above the vault helps heat protection. Its volume also reduces temperature. Although ventilating deep cellars is more difficult than the ones above the ground level, their usage in wine storing is inevitable [2] (Figure 24). 


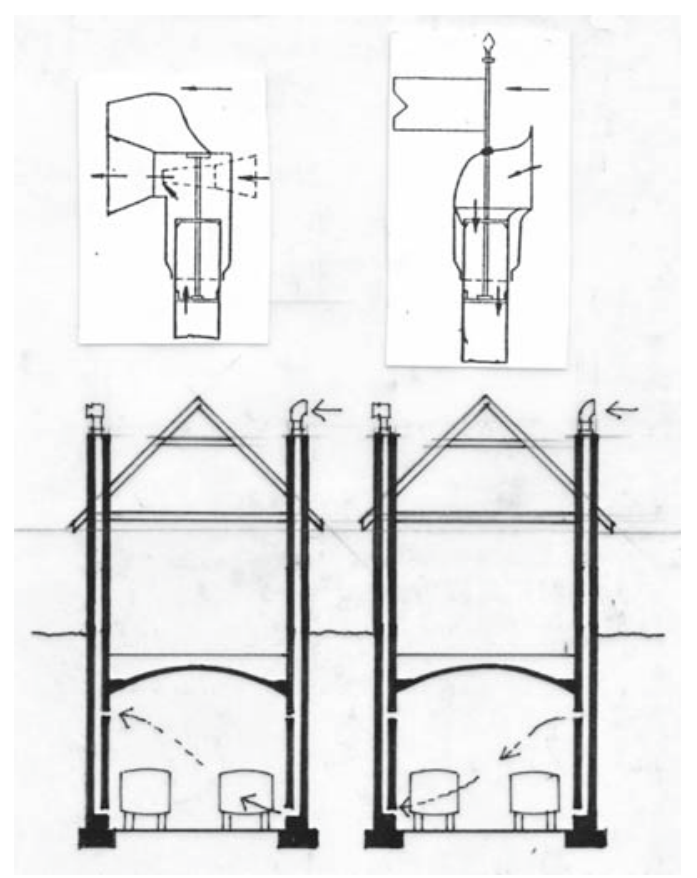

Figure 24 Air-ducts for gravitational ventilation in a wine storing cellar under a building [6]

\section{LIVESTOCK KEEPING}

In livestock keeping it is essential that most animals prefer vapour-, dust- and draught-free and dry resting places. There is a considerable difference between the air temperature of the stable and the temperature sensation of the animals. Among the factors influencing animals' temperature sensation it must be mentioned that in case of both outdoor and litter bedding livestock keeping animals, having the opportunity to choose a resting place meeting their demands, are able to tolerate greater changes of temperature. Temperature sensation is also influenced by the quality of the boarding of the resting place, the humidity and the motion of air [2].

\subsection{Cattle keeping}

Natural ventilation can easily be carried out in double row barns with adjustable ridge ventilators. In buildings open at both ends draught must be minimized in winter. In buildings open at one end cross-ventilation must be ensured in summer.

As regards experimental model buildings the half block units' most favourable solution is a $3 \times 6 \times 7,5$ metres pillared steel structure with middle high roofed saw-toothed cross-section because it facilitates natural ventilation and lighting even in case of a four-row ground plan (Figure 25). 


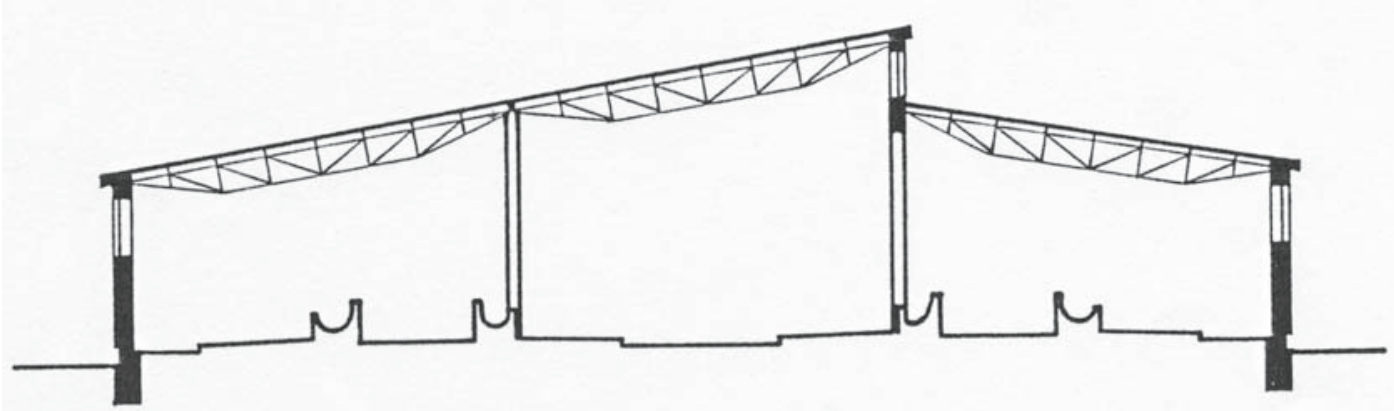

Figure 25 Middle high roofed saw-toothed design of half block unit cattle barns facilitating natural ventilation

The barn suitable for outdoor livestock keeping in Tiszadob is attached to a foil house which can be folded down in summer and is suitable for growing plants in winter. Thanks to its structure the natural ventilation of the building is differentially resolved (Figure 26).

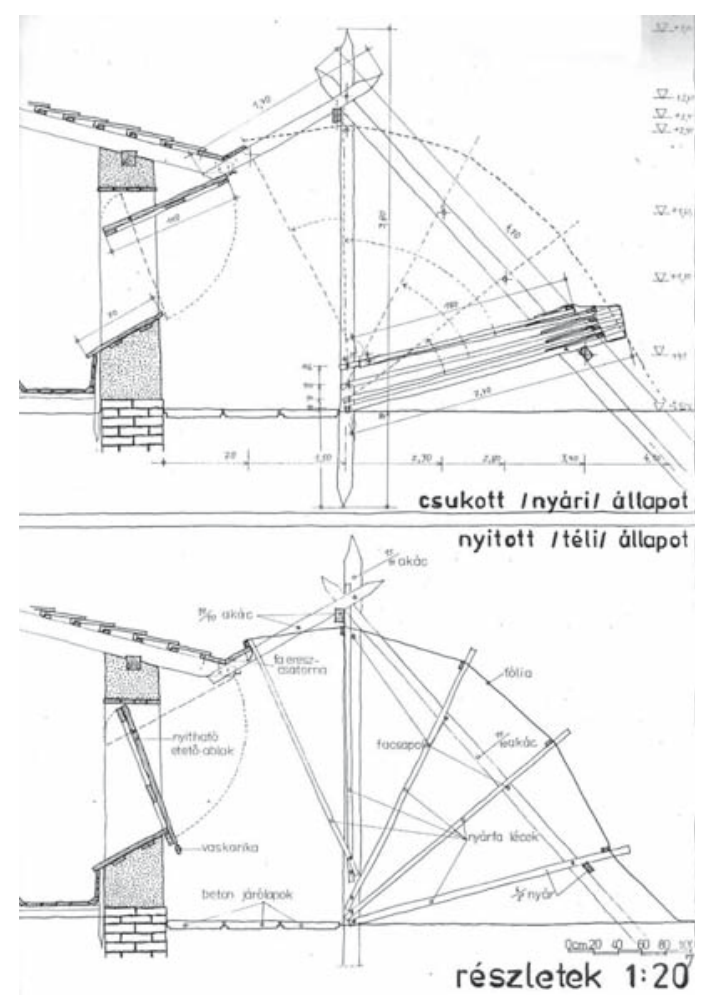

Figure 26 Foil-house attachment using alternative passive energy of the barn in Tiszadob designed for exploiting changes of seasons (architect: Zsuzsa Netkovszky) 
The ventilation and heat insulation of the economical rig timber family barn in Bercel is also carried out naturally. Winter fodder by the wall of the building serves for heat insulation (Figure 27).

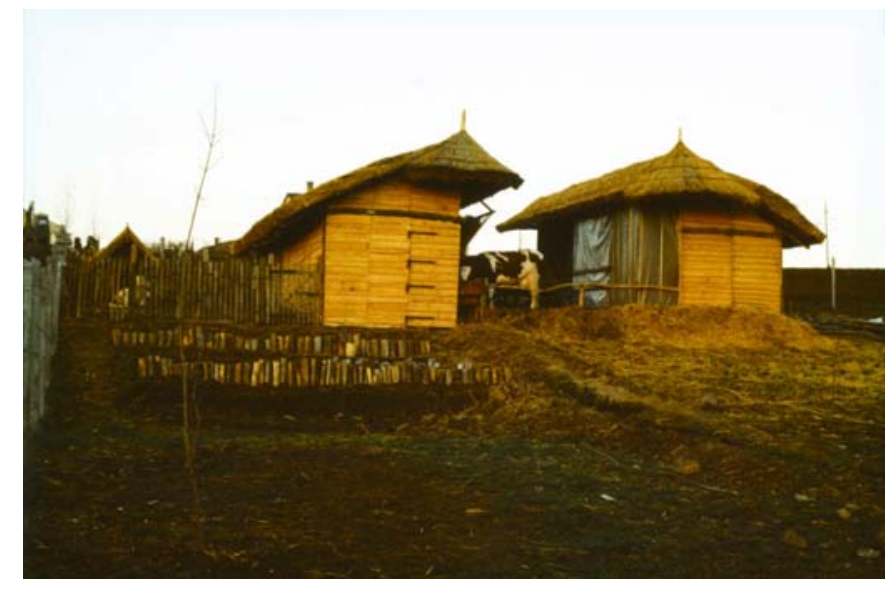

Figure 27 The oriented and open economical family barn in Bercel (architect: Dr. Gábor Ónodi)

\subsection{Pig keeping}

The places of ecological pig keeping can be partly open buildings or wandering non-building sties. The longitudinal side of these buildings is oriented towards south, the longitudinal axis of the building is perpendicular to the prevailing wind direction, summer cross-ventilation is ensured by vertical lathing, which can be surrounded by straw bales in winter [4].

Definite distinction has to be made between winter and summer ventilation of pig sheds. In winter the warmer used air has to exit near the roof ridge with the least possible air motion in the animals' resting area. In summer the animals require the cooling effect of air, which can be ensured by effective cross-ventilation. The quality of the sty's floor, the intensity of bedding and the maintenance of the litter greatly influence the temperature sensation of the animals.

The aim of designing the economical and environmentally friendly ISV pig farm was to make a wooden building with minimal investment and running cost without power ventilation and heating. The whole southern side of the building can be opened, the foiled wooden frames let the sunshine in when necessary (passive solar energy) end ensure intensive ventilation in opened state. On the northern side the underneath panel ventilating stripe ensures summer draught effect and ventilation, whereas the upper ventilating stripe near the ridge ensures winter ventilation (Figure 28).

The experimental pig farm building in Paks has proved that natural ventilation can be achieved in wider buildings as well if both longitudinal side walls can entirely be opened and upper ventilation is built up at full length of the ridge. The manually adjustable convertible foiled frames ensure natural ventilation. Heat insulation is provided by well-fixed reed walling (Figure 29). 

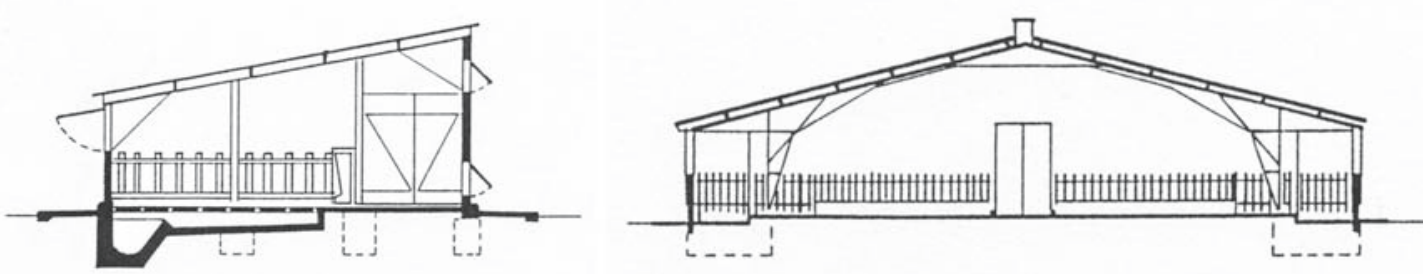

Figure 28-29 Symmetric and asymmetric cross-ventilating buildings of ISV pig farm and experimental pig farm in Paks [6]

When designing the pig sheds of the Farming School in Kenderes natural ventilation was a primary concern. Outflow of air is ensured by the ridge ventilation of the oriented, half-pitched roofed building, whereas inflow of air and natural lighting is provided by the removable, foiled framed windows. Straw bale heat insulation can be found by the northern walls (Figure 30).

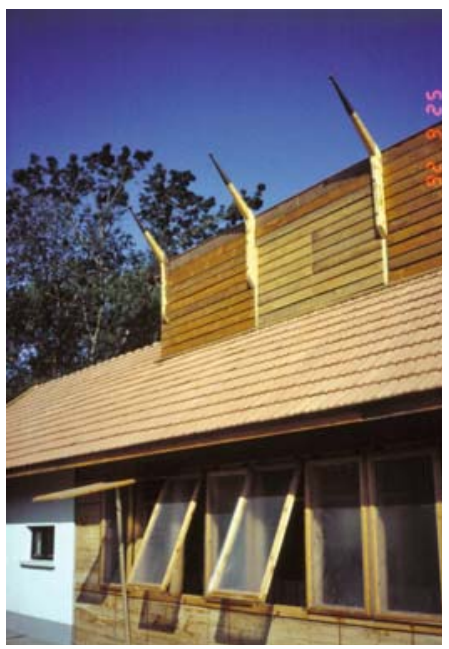

Figure 30 Convertible foiled framed windows of simple pig sheds in Kenderes with natural ventilation, lighting and heat protection and heat preservation (architect: Dr. Gábor Reischl)

\subsection{Horse breeding}

Some horse breeds can be kept outdoors in barn-like stables with a west-east longitudinal axis and open southern side sheltered from wind [4]. Special care must be taken of the quality and flow of air in horse stables. The stables are unheated but heat insulated with excellent heatpreserving capacity (heat generated by the animals ensures adequate heat sensation). For the sake of appropriate air flow, hopper casements are applied on the side walls under the ceiling complemented with roof ventilators. The pitched roofed structure of stables facilitates heat levelling in the loft space, which has a storing function as well (Figure 31). (E.g.: The hay stored in the loft provides for heat insulation of the floor.) 


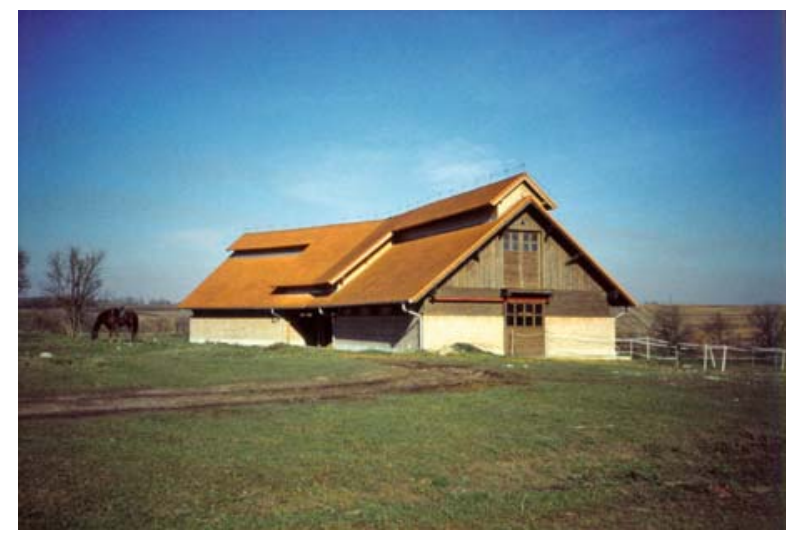

Figure 31 Ridge ventilators ensuring natural ventilation in a stable in Mende (architect: Dr. Gábor Reischl)

\subsection{Poultry breeding}

The longitudinal axis of fowl-houses and chicken-runs must be oriented to south or southwest in order to get enough sunshine and be protected from wind. In summer plants should shade both the poultry-house and the chicken runs. Natural ventilation and lighting is ensured by convertible, evenly partitioned window structures on the longitudinal side of the fowlhouse. Sunshine also has a sterilizing and passive heating effect in winter and in transitory seasons. (In case of appropriate heat insulation and double-glazing no heating is necessary.) Glass surfaces, which mean at least 20 per cent of the floor-space, must be shaded in summer in order to prevent over-warming. Curtains made of sackcloth or straw must be placed in the inner side in order to prevent over-cooling in winter [4]. Differentiated ventilation facilities should be taken into consideration when designing the walls and roof structure of sheds.

Ventilation was a crucial element of the operation the bio chicken-farm in Tornyiszentmiklós as well. The air comes into the first shed through blowholes on the wall and it exits at the ridge of the new, heightened roof structure (Figure 32, 33).
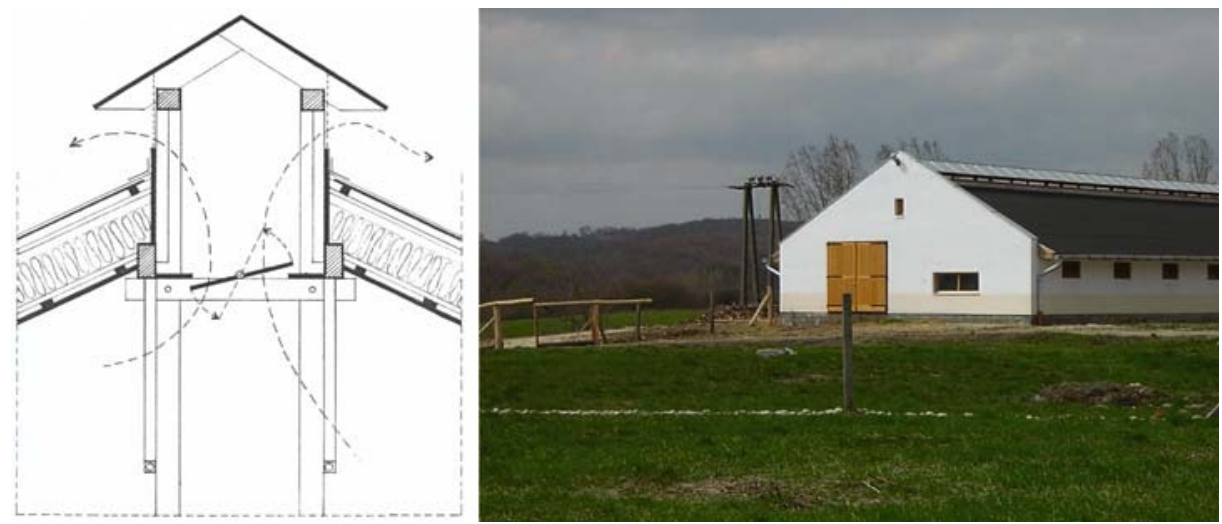

Figure 32-33 Heightened ridge ventilator in a fowl-house in the bio chicken-farm in Tornyiszentmiklós (architects: Dr. Gábor Reischl, Zoltán Laczó) 
In the other shed, which originally had been built with a metal trussed granary attic, ventilation was achieved by altering the original roof form. Ventilator windows and doors fitted in the roof are manually operated with the help of visible strings, which is a unique solution. Beyond appropriate ventilation the light demand of the poultries was also taken into consideration. Several lantern-light roof stripes and reflecting wall surfaces were designed [5] (Figure 34, 35).
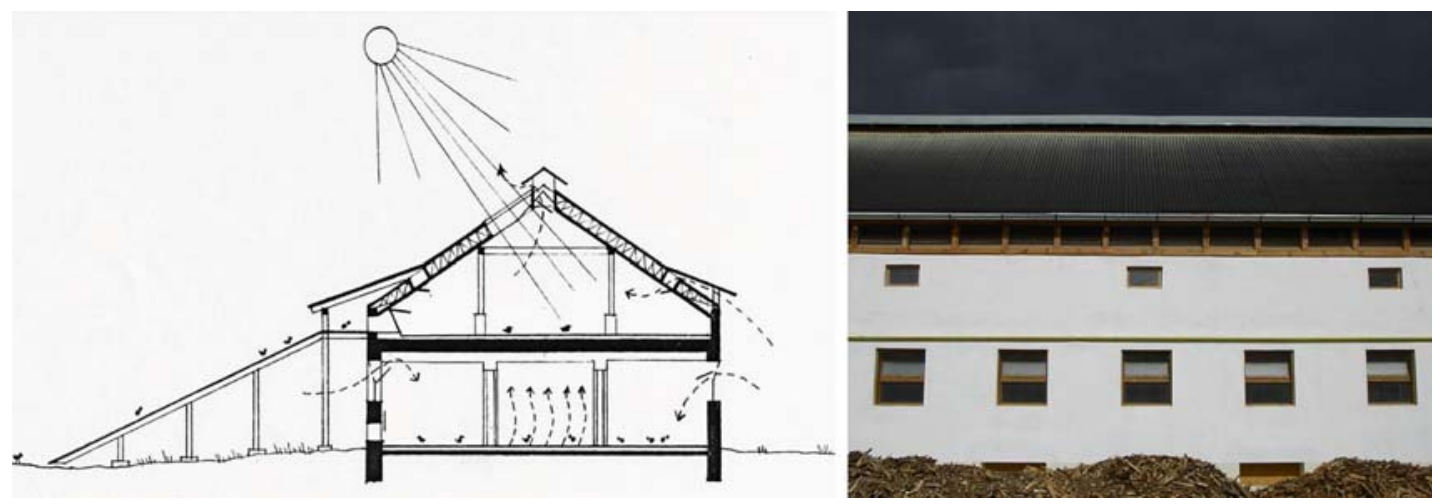

Figure 34-35 Converted two-storied shed with a granary attic in the bio chicken-farm in Tornyiszentmiklós with side and ridge ventilation (architects: Dr. Gábor Reischl, Zoltán Laczó)

\subsection{Sheep keeping}

In accordance with outdoor breeding, sheep barns have an open southern side and three closed sides (parts of which can also be opened to ensure summer cross-ventilation). In order to achieve natural ventilation it is necessary that the width of the building should not be more than 12 metres and its length should be less than 60 metres. With these parameters draught-free ventilation can be carried out through doors and windows and adjustable ridge ventilators. (For 100 square metres barn area 0.3 square metres ventilating flue is needed.) Considering natural ventilation, winter heat insulation and the exit of ammonia, the application of a thatched roof and double gates with upper ventilators are quite favourable. Appropriate natural lighting can be achieved if the superficial extent of windows reaches at least one fifteenth to one twentieth of the basic area of the building [4]. Thatched pitched roofs generate good air conditions, as vapour diffusion becomes optimal and there is no moisture precipitation [2] (Figure 36). 


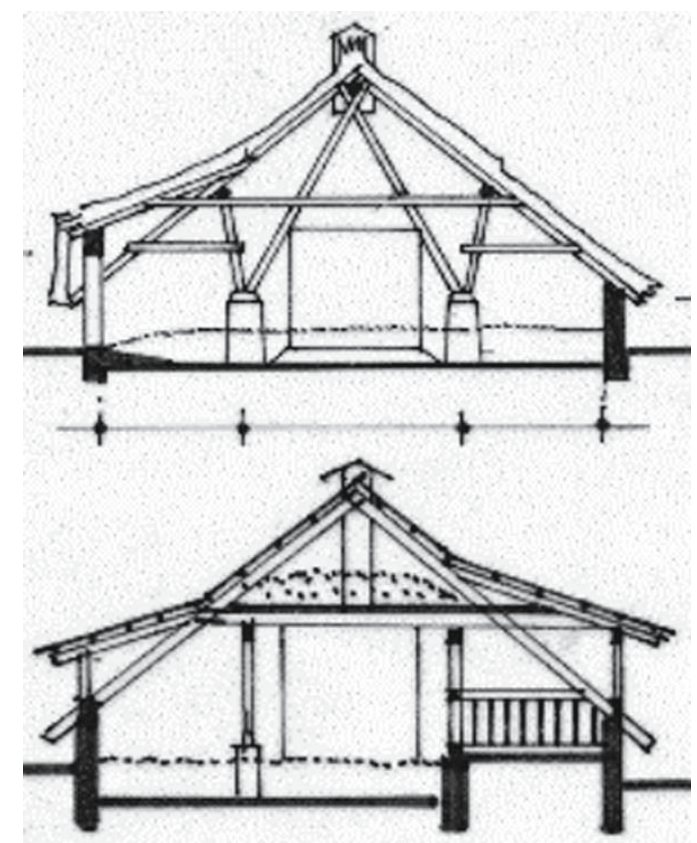

Figure 36 Planning schemes of thatched sheep barns without attic and tile roofed sheds with fodder storing attic allowing natural ventilation [6]

\section{CONCLUSION}

The history of eco (organic) farming in Hungary has begun nearly 30 years ago in 1983, with the foundation of „Bioklub”. Currently, about 120,000 hectares of land - approx. 2\% of the agricultural area is managed this way. According to a rating by „Biokontroll”, about 1000 Organic Farms operate matching EU standards, not using artificial materials and devices neither in growing crops nor livestock.

The market for organic foods is spreading around the world, so this process is likely to happen in Hungary, as well. The Hungarian countryside - besides being suitable for largescale technologies - can very well accommodate the small-scale production methods to match special needs, just as well. A reinterpretation and modernization of traditional techniques can achieve a great deal in this field.

There are extensive works describing the technological processes of organic farming. But there is not any comprehensive architectural analysis on the building stock of the organic farming method. Buildings that are used for growing crops, keeping livestock, or storage, and correspond the characteristics of the up to date advanced technologies, the local production needs, as well as domestic climatic conditions. The present research gives a survey on the architectural backgrounds of this specific land management type. Sustainability and energy conservation is one of the most significant concept of our time. The energy crisis and climate change have brought along a new demand in the construction industry, including design and operation of agricultural buildings: the usage of energy efficient, environmentally friendly and preferably renewable energy based building alternatives. 
Among the energy-saving solutions I would like to emphasize those passive systems in particular, which use the natural conditions (sunlight, shading, ventilation, gravity, etc.) on their own, without the help of mechanical equipment, and achieve energy efficiency by placing and structuring technological buildings accordingly.

The significance of passive use of energy in agricultural architecture, lies mostly in the ventilation and heating/cooling, but substantial savings can be achieved by using passive methods in temperature and humidity control, as well as in certain farming technologies.

As an overall establishment, the majority of animals prefer a dry, humidity-, dust-, and draftfree place to rest, but they also have specific ethological needs. These, methods of passive use of energy, the specific circumstances of individual sites, and design-guidelines can all be integrated. Passive energy methods can be applied successfully for cultivation and storage of plants, but this field is species and location specific just as well.

The study shall display some implemented pilot projects, and farms in addition to the detailed survey of the above. The goal of this research is the systematic analysis of all these phenomena, solutions, examples, subsequently, providing architectural recommendations for future developments.

\section{REFERENCES}

[1] SÁrközi, S., Seléndy, Sz., (Barótfi, I.) Biogazda 3, Biokultúra egyesület, Lehen und Umwelt, 1994, pp. 320-323.

[2] Reischl G. Gazdálkodó építészet, manuscript, 2005.

[3] Farkas I. (Szűcs M.): Napenergia a mezőgazdaságban, Mezőgazda Kiadó, Budapest, 2003, pp. $219-223$.

[4] Radics L., Seregi J. (Bódi, Szendrő, Szücs, Szüle) Ökológiai szemléletű állatitermék-előállítás, Szaktudás Kiadó Ház, Budapest, 2005

[5] Csontos Gy. Biocsirke és a „low-tech”, Építömester, Bertelsman, Budapest, 2003/5.

[6] Reischl G., Szűcs M. A gazdálkodás építészete. Szaktanácsadási füzetek 4. sz. GATE Vidékfejlesztési é Szaktanácsadási Központ, 1996-1997 